\title{
A tribute to Gerald Weissmann (1930-2019)
}

D tus at New York University School of Medicine, a long-standing member of the American Society for Clinical Investigation, and a former president of the American College of Rheumatology (1983-1984), was a larger-than-life force in academic medicine and biomedical research. With his passing on July 10, 2019, medicine lost a genuinely exceptional physician, scientist, writer, and mentor to many. As chief of the Division of Rheumatology at NYU's Langone Medical Center (1973-2000), Weissmann trained scores of academic clinician-scientists in internal medicine and rheumatology. His enormous intellect and capacity for scholarship shall be greatly missed. Dr. Weissmann wore many hats, but to all, he was a guiding light in scientific rigor, evenhandedness, and unbounded enthusiasm for scholarship in the world of biomedical sciences. In this tribute, we provide some comments from a few of Dr. Weissmann's many colleagues and trainees.

Gerald Weissmann (Figure 1) was born in Vienna, Austria, in 1930 and left with his parents in 1938, escaping Europe's turmoil to settle in New York City, where his father resumed the practice of medicine. After earning an undergraduate degree from Columbia University, Gerry completed medical school in 1954 at NYU School of Medicine. Dr. Weissmann completed his residency at Mount Sinai Hospital and returned to NYU, where he served as the first chief resident under Lewis Thomas, MD, Chairman of Medicine, who would later become the dean. Dr. Weissmann remained at NYU, continued his very successful trajectory, and was appointed the founding director of NYU Langone's Division of Rheumatology, serving from 1973 to 2000 .

Dr. Weissmann was internationally known for his contributions to the molecular mechanisms of inflammation and the biochemistry of lipids and eicosanoids. Dr. Weissmann began his education at the Art Students League of New York, where he prepared for a career in fine art.

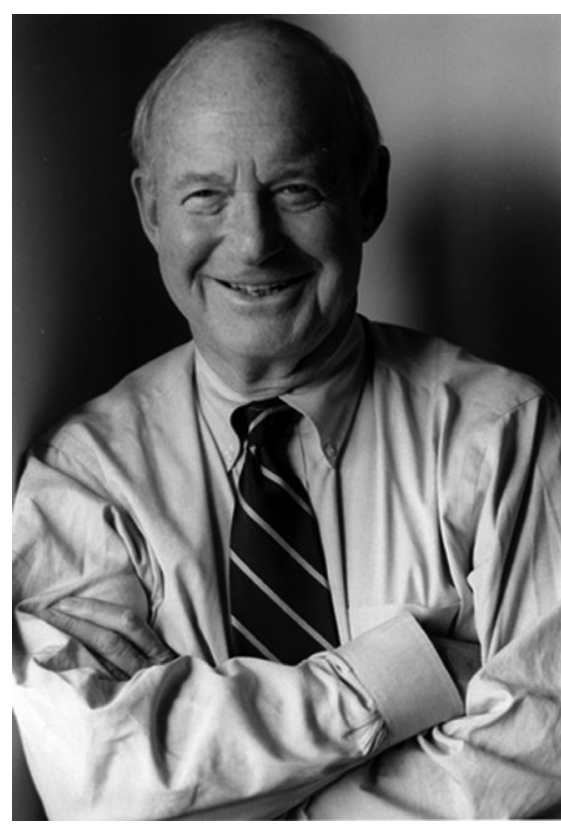

Figure 1. Gerald Weissmann. Image credit: Leonard Nones.

His father, a Vienna-trained physician with a strong interest in the rheumatic diseases (before there was such a specialty as rheumatology), brought his aspiring artist son, in the early 1950 s, to a lecture on corticosteroids and their use in the treatment of rheumatic diseases. Gerry recalled that this was a pivotal event that led to a change in his educational goals. His career defined in many respects what we consider today a physician-scientist, but with an artistic flair.

Gerry's research began in the laboratory of Dr. Thomas, where his interests were further captivated by studies in the area of inflammation. In 1964 he co-authored one of his first papers with Dr. Thomas in the Journal of Cell Biology, reporting on results of neutrophil lysosomes in the now famous rabbit ear experiments, in which the neutrophils' lysosomal contents spilled to damage the ear cartilage, making the ear droop (1). Following up on basic lysosome biology, in 1972 Gerry became the fifth organizer of the Lysosome Gordon Research Conference, founded in 1967 by Christian de Duve. With a solid background in cell biology, Dr. Weissmann marched onward and upward in a career that led him to become a world-renowned scientist, rheumatologist, mentor, and scholar. As the son of a practicing physician, he kept in mind that patients were at the center of his work. Dr. Weissmann is best known for uncovering evidence that identified rheumatoid arthritis as an immune complex disease and for demonstrating that crises in systemic lupus erythematosus are evoked by intravascular complement activation. Gerry authored many pioneering studies on leukocyte activation and the role of salicylates and corticosteroids in regulating cell signaling responses. In the mid-1960s, in efforts to better understand the antiinflammatory mechanism of corticosteroids, he co-discovered liposomes, phospholipid vesicles that have become crucial tools widely used in the laboratory and in clinical practice for the delivery to tissues of many bioactive substances, including genes, drugs, and nutrients $(2,3)$.

Gerry received numerous distinctions and awards. He was a fellow of the American Association for the Advancement of Science and the Royal Society of Medicine. He was elected in 2002 to Galileo's Accademia Nazionale dei Lincei of Rome, the world's oldest scholarly society. This honor was particularly fitting because, by studying portraits of Galileo, Gerry surmised that the astronomer suffered from gout, which he later wrote about in his 2007 book Galileo's Gout (vide infra). He also received two of the American College of Rheumatology's highest honors: the Presidential Gold Medal and the Lifetime Achievement Award. At NYU, Gerry was recognized in 2009 as a Master Educator and Mentor. From 1975 to 2001, he served as the founding editor of the journal Inflammation, and from 2006 to 2015, he was editor-in-chief of The FASEB Journal. He was serving as the journal's book reviews editor at the time of his death.

Dr. Weissmann was dedicated to education. While setting the highest expectations, Gerry always provided encouragement. Despite his own myriad accomplishments, his greatest pride was in the success of 
those he trained. In the laboratory, he was well known for the phrase, "That's a wow!" extolled when a young investigator presented interesting new results. Gerry handpicked his fellows and taught them how to lead by example, to dissect a research problem down to its bare bones, to write the Queen's English (never a noun as an adjective, always the active voice), and to deliver a masterful presentation (hours spent slide by slide, color for color for each graph on all of the slides for every talk from his lab). Dr. Weissmann was a gentleman-scholar, a role model for many, and when he spoke to you about experiments, you knew it was from the heart.

Gerry Weissmann ignited a spark in countless lives. Those fortunate enough to have grown under Gerry's wings probably feel as we do, that a major pillar of our foundation is now missing. We all miss his famous purple magic marker that annotated the work we submitted to him and showed us ways to deliver the significance of our discoveries in a crisp and focused communication that could be understood by all. Even those who met Gerry only briefly, or simply attended his lectures at national meetings, appreciated this universal man of grand proportions who enlightened our fields for decades.

In conferences, lab meetings, and informal discussions, Gerry's raised eyebrow was a "tell," a tipoff that a pun was on its way. Puns were only the start; nearly any comment, whether it had to do with a patient or a finding in the lab, could set off a series of associations leading to a completely unexpected comment or idea. Like a great jazz musician, Gerry's riffs were novel, surprising, funny, sometimes silly, but often profound. Taking his cue from Diderot, Gerry's knowledge was encyclopedic, and the number of facts and associations that could come together in his mind was truly remarkable.

Gerry had enormous respect for the intellectual origins of an idea and the art of scientific investigation. What was most important for us as his trainees was that he wouldn't hold onto a hypothesis if it had been tested and found wanting. The ability to abandon a position not supported by the facts is critical to the progress of science as well as the scientist. Gerry was a master scientist, and this is one of the most lasting lessons that he imparted to his grateful trainees. Many of Dr. Weissmann's trainees went on to lead distinguished careers and remained close to him throughout his life.

In his college, medical school, and residency years, Gerry's domain was Manhattan, but from his mentor, Lewis Thomas, he heard about another mecca, not one of medicine but of biology - the Marine Biological Laboratory (MBL) at Woods Hole, Massachusetts. In due course, Gerry came to MBL, and it became for the rest of his life a powerfully enabling complement to his NYU career. He became an annual summer investigator, initiating studies of inflammation-like cellular events in certain marine organisms whose simplified versions of the human phenomena afforded an opportunistic window for insights.

During these years, his zest as an essayist bloomed. Although he would arrive at Woods Hole in June with a research article from his NYU lab still to be finished, and while in August he had another manuscript in the works from his summer work, he managed to steal away on certain days and write essays for various publications. These were for a broader scientific audience than his peers in rheumatology and immunology and displayed an uncommon nimbleness of apt metaphor, typically a link of the biological subject at hand with something in art, music, or history. These essays resulted in his first book, deftly titled The Woods Hole Cantata: Essays on Science and Society (4). In his later career, Gerry's summers at MBL were devoted exclusively to writing, with an enormous output. By then, he had achieved a place in the pantheon of literary scientists that includes Lewis Thomas, Carl Sagan, and Thomas Huxley.

All those summers of writing were spent in a bicameral mode - mornings at the famed MBL Library (a modern analog for biology of what the Library of Alexandria housed in antiquity), lunch at his nearby house with his beloved wife, Ann, and then an afternoon of more writing in his study there. Over the many years when his colleagues would see him walking from the MBL Library to his house around noon, we suspect they had the thought, "There has never been a more perfect person for MBL." Nor a more perfect setting for his métier. Each summer at the MBL, another dimension of Dr. Weissmann emerged: planning experiments, writing essays and scientific manuscripts, and conversing with colleagues on the principles in biology that could impact medicine and patient care. And oh, yes, tennis too.

Throughout his career, Gerry wrote and published literary essays. His writing appeared in The New York Times Book Review, the London Review of Books, and The New Republic, among other venues. His work has been collected in nearly a dozen book-length volumes, including The Woods Hole Cantata: Essays on Science and Society (4), Darwin's Audubon: Science and The Liberal Imagination (5), Galileo's Gout (6), Mortal and Immortal DNA (7), Epigenetics in the Age of Twitter (8), and, most recently, The Fevers of Reason (9). As an essayist, Gerry was elected to PEN International, the prestigious society of writers. Gerry was twice awarded sabbaticals at the Rockefeller Foundation Bellagio Center (a rare scientist among artists and writers). In age-old literary tradition, Gerry the polymath flourished during his annual winter sojourns with Ann on Île Saint-Louis, Paris.

Dr. Weissmann was blessed with a wonderful family. He is survived by his wife, Ann, a true lifetime partner of over 65 years; his daughter, Lisa Beth Weissmann, MD, Chief of Hematology/Oncology at Mount Auburn Hospital in Cambridge, Massachusetts, and her son Ben; and his son, Andrew Weissmann Esq., distinguished senior fellow at NYU School of Law and former chief of the Division of Criminal Fraud in the Department of Justice. Gerald Weissmann was a unique and exceptionally talented individual in all his endeavors. He inspired us all with his immense knowledge, creativity, and kindness. We all mourn his passing.

\section{Steven B. Abramson, Paul J. Anderson, Jill P. Buyon, Bruce N. Cronstein, Thoru Pederson, Mark R. Philips, and Charles N. Serhan}

Address correspondence to: Charles N. Serhan, Brigham and Women's HospitalHarvard Medical School, 60 Fenwood Road, HBTM 3016, Boston, MA 02115, USA. Phone: 617.525.5001; Email: cserhan@bwh. harvard.edu. 
1. Weissmann G, Becher B, Thomas L. Studies on lysosomes v. the effects of streptolycins and other hemolytic agents on isolated leucocyte granules. J Cell Biol. 1964;22:115-126.

2. Bangham AD, Standish MM, Weissmann G. The action of steroids and streptolysin $S$ on the permeability of phospholipid structures to cations. JMol Biol. 1965;13(1):253-259.

3. Weissmann G, Claiborne R, eds. Cell Membranes: Biochemistry, Cell Biology \& Pathology. New York,
New York, USA: HP Publishing Co.; 1975.

4. Weissmann G. The Woods Hole Cantata: Essays on Science and Society. New York, New York, USA: Dodd, Mead \& Company; 1985.

5. Weissmann G. Darwin's Audubon: Science and The Liberal Imagination. New York, New York, USA: Basic Books; 2002.

6. Weissmann G. Galileo's Gout: Science in an Age of Endarkenment. New York, New York, USA: Bellevue Literary Press; 2007.
7. Weissmann G. Mortal and Immortal DNA. New York, New York, USA: Bellevue Literary Press; 2009.

8. Weissmann G. Epigenetics in the Age of Twitter: Pop Culture and Modern Science. New York, New York, USA: Bellevue Literary Press; 2012.

9. Weissmann G. The Fevers of Reason: New and Selected Essays. New York, New York, USA Bellevue Literary Press; 2018 